\title{
SURVEY OF BENGAL FLORICAN HOUBAROPSIS BENGALENSIS BENGALENSIS (GMELIN, 1789) (GRUIFORMES: OTIDIDAE) IN THE KOSHI TAPPU WILDLIFE RESERVE AND ADJOINING AREAS, NEPAL
}

ISSN

Online 0974-7907

Print 0974-7893

\section{Hem Sagar Baral 1,5, Ashok Kumar Ram ${ }^{2}$, Badri Chaudhary ${ }^{3}$, Dheeraj Chaudhary ${ }^{4}$, Anish Timsina ${ }^{4}$, Sanjib Acharya ${ }^{5}$, Krishna Bidari ${ }^{4}$, Suman Acharya ${ }^{4}$, Binod Acharya ${ }^{4}$, Prem Thulung ${ }^{4}$, Arjun Karki ${ }^{4}$ \& Krishna Prasad Acharya ${ }^{6}$}

${ }^{1}$ School of Environmental Sciences, Charles Sturt University, NSW Australia

${ }^{2}$ Koshi Tappu Wildlife Reserve, Department of National Parks and Wildlife Conservation, PO Box 860, Babarmahal, Kathmandu, Nepal

${ }^{3}$ Nepalese Ornithological Union, PO Box 21016, Thamel, Kathmandu, Nepal

${ }^{4}$ Koshi Bird Society, Prakashpur, Sunsari, Nepal

${ }^{5}$ Kosi Bird Observatory, Himalayan Nature, PO Box 10918, Lazimpat, Kathmandu, Nepal

${ }^{6}$ Department of National Parks and Wildlife Conservation, PO Box 860, Babarmahal, Kathmandu, Nepal

Email: ${ }^{1}$ hem.baral@gmail.com (corresponding author), ${ }^{2}$ rashok05@gmail.com, ${ }^{3}$ info@birdsofnepal.org,

${ }^{4}$ koshibirdsociety@gmail.com, ${ }^{5}$ info@himalayannature.org, ${ }^{6}$ kpacharya1@hotmail.com

\begin{abstract}
The Bengal Florican Houbaropsis bengalensis is a Critically Endangered bird species. Populations have been monitored in Nepal since 1982, and the most recent study showed a precipitous decline despite the species being mainly confined to protected areas. A systematic survey was conducted in parts of the Koshi area during April and May 2012 by walking transects in known and accessible grasslands. The total of 47 birds counted during this survey represents the largest known population in Nepal, and perhaps the most densely populated area in the entire Indian subcontinent. A crude extrapolation of the count for the entire Koshi area gives an estimate of 60 birds. Several conservation recommendations have been made to ensure florican populations continue to thrive in the Koshi Tappu area.
\end{abstract}

Keywords: Bengal Florican, Koshi Tappu, Nepal, population survey.

DOI: http://dx.doi.org/10.11609/JoTT.03240.4076-83 | ZooBank: urn:Isid:zoobank.org:pub:75116FBC-FE2C-46A7-90E9-9088504E53B0

Editor: K.S. Gopi Sundar, International Crane Foundation, USA

Date of publication: 26 April 2013 (online \& print)

Manuscript details: Ms \# 03240 | Received 26 June 2012 | Final received 29 March 2013 | Finally accepted 01 April 2013

Citation: Baral, H.S., A.K. Ram, B. Chaudhary, D. Chaudhary, A. Timsina, S. Acharya, K. Bidari, S. Acharya, B. Acharya, P. Thulung, A. Karki \& K.P. Acharya (2013). Survey of Bengal Florican Houbaropsis bengalensis bengalensis (Gmelin, 1789) (Gruiformes: Otididae) in the Koshi Tappu Wildlife Reserve and adjoining areas, Nepal. Journal of Threatened Taxa 5(7): 4076-4083; http://dx.doi.org/10.11609/JoTT.o3240.4076-83

Copyright: (c) Baral et al. 2013. Creative Commons Attribution 3.0 Unported License. JoTT allows unrestricted use of this article in any medium, reproduction and distribution by providing adequate credit to the authors and the source of publication.

Funding: The project was funded by Himalayan Nature, Charles Sturt University Australia, Koshi Tappu Wildlife Reserve and The Wetland Trust UK.

Competing Interest: None.

Acknowledgements: We acknowledge the firm support and guidance from the staff of the Department of National Parks and Wildlife Conservation (DNPWC) towards the conservation of birds of Nepal through Himalayan Nature. We would especially like to thank Dr. Maheshwor Dhakal, ecologist, DNPWC for his support in facilitating the research permit for this study and for being so supportive to our research work all over Nepal. We would also like to thank support of Laxman Prasad Poudyal, Bengal Florican researcher and staff at the DNPWC for his support to ensure the best results from this survey. We would like to thank and acknowledge the staff of Koshi Tappu Wildlife Reserve for the support to our conservation activities inside and outside the reserve. We thank Himalayan Nature/Kosi Bird Observatory supported by the Tiger Mountain Pokhara Lodge, Charles Sturt University-Australia, Van der Hucht de Beuklaar Foundation, Van Tienhoven Foundation, The Peregrine Fund USA, Manfred-Hermsen-Stiftung-Germany and Parahawking: Share the Sky. We would like to thank Prof. Karan Bahadur Shah, Sharad Singh, Prativa Kaspal, Prava Pandey and Saswot Sharma for extending support and back up. We also thank Koshi Camp Pvt. Ltd. run by Nature Safari Tours Pvt. Ltd. and Naturetrek Ltd. for help in logistics. We would like to thank Badri Nath Pudasaini and Bhesh Raj Ghimire, Directors of Koshi Camp for their support; Buddhi Prasad Timsina, Dhan Bahadur Karki and Tika Ram Sherpa of Kosi Bird Observatory, Dik Bahadur Magar, Som Magar, Shumsher Magar, Umesh Chaudhary and Rajji Uranwa of Koshi Camp, Tika Basnet, Yogananda Pathak, Shree Ram Giri, Jagat Giri, Dr. Vivekananda Jha and Chandra Shekhar Chaudhari of Koshi Tappu Wildlife Reserve; Tika Giri and Hathan Chaudhary of Nepalese Ornithological Union for having extended their support for this survey; Carol Inskipp, Laxman Prasad Poudyal, Suchit Basnet (Chair of Nepal Rare Bird Council) and Dr. Nabin Baral for their advice and comments for the survey and for this paper.
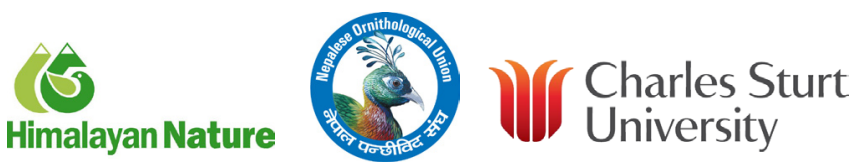


\section{INTRODUCTION}

The Bengal Florican Houbaropsis bengalensis is considered to be one of the rarest bustard species in the world (Hoyo et al. 1996), and was at one time described the most threatened bird species in the Indian subcontinent (Inskipp \& Collar 1984). It is now listed as Critically Endangered (BirdLife International 2012). This florican inhabits alluvial grasslands located in India from the Kumaon Terai of Uttar Pradesh (now Uttarakhand) through Bihar and West Bengal to the foothills and plains of Arunachal Pradesh, Assam and Meghalaya, in the Nepal Terai and in Cambodia and southern Vietnam (Ali \& Ripley 1987; BirdLife International 2012). Two subspecies have been recognised: H.b. bengalensis from the Indian subcontinent and H.b. blandini from Cambodia and Vietnam (Hoyo et al. 1996). Populations have declined chiefly as a result of habitat loss and hunting, and in the Indian subcontinent the taxon now mostly inhabits protected areas (BirdLife International 2012).

A pioneering study on this species in some of the protected areas in Nepal's southern belt and northern India was conducted in 1982, resulting in an estimate of 56-82 birds as the total Bengal Florican population in Nepal (Inskipp \& Inskipp 1983). The study concluded that in Nepal all important populations of the species lie within lowland protected areas. A number of studies has been carried out since then, notably in Suklaphanta Wildlife Reserve and Bardia National Park in 1990 by Weaver (1991), Bardia in 1998 by Pokharel \& Dhakal (1998) and Suklaphanta Wildlife Reserve, Bardia and Chitwan National Parks in the years 2000-2001 by Baral et al. (2003). Repeated surveys have found population declines in three protected areas of the central and western Nepal (Baral et al. 2003; Poudyal et al. 2008). A re-visit to Nepal's lowland protected areas further confirmed the degradation of grasslands (Inskipp \& Inskipp 2001). These studies have concluded that the biggest threat to the Bengal Florican in the protected areas is improper management of the species' grassland habitats. Grassland management has been haphazard and without scientific basis, and there has been minimal record keeping of changes brought about by management practices. In many cases areas were cleared and ploughed to increase animal sighting for visiting tourists (Hem Sagar Baral pers. obs. 1996). Poudyal et al. (2008) provide the most up to date information on this species from Chitwan, Bardia and Suklaphanta, then major Nepal strongholds of the species with an estimate between 28-36 adult birds in Nepal, and more recently several birds have been found in Koshi (Baral et al. 2012). Until recently the Koshi area was largely neglected because of the belief that it held only a small population.

A thorough survey in Koshi Tappu Wildlife Reserve and its adjacent areas was recommended to determine an accurate estimate of the population and status of Bengal Floricans (Poudyal et al. 2008; Baral et al. 2012). This survey aimed to cover the grasslands of Koshi area including Koshi Tappu Wildlife Reserve and its surrounding areas to provide an estimate of their population and present recommendations for Bengal Florican conservation.

\section{STUDY AREA}

Koshi Tappu Wildlife Reserve (=Koshi Tappu hereonwards, centered at $26^{\circ} 35^{\prime} \mathrm{N} \& 87^{\circ} 05^{\prime} \mathrm{E}$ ) occupies $175 \mathrm{~km}^{2}$ of the Sapta Koshi River floodplain at the most northeasterly extension of the Gangetic Plain (Fig. 1). It ranges in elevation from 75-81 m (Sah 1997). The reserve is located between two flood control embankments and is subject to high annual inundation during the months of July and August. An estimated $70 \%$ of the reserve's land area is covered by 'phantas' (patches of short grasslands), water and riverine forests. Typha spp. and Saccharum spp. are the dominant plant species here, although patches of Imperata spp. and Phragmites spp. are also seen (Peet et al. 1999). Short height grasslands that occupy few square meters to several hectors are found interspersed with young Dalbergia sissoo and Acacia catechu trees on sandy islands. Riverine vegetation dominated by $A$. catechu and $D$. sissoo trees dominates the islands and edges of the reserve. The wetlands in the reserve were declared as Nepal's first Ramsar site for the large congregation of waterbirds it holds during winter and its resident Asian Wild Buffalo Bubalus arnee population (Sah 1997). Koshi Tappu has been a Ramsar Site since 1987 and together with wetlands of Koshi Barrage which lies $6 \mathrm{~km}$ south of the Koshi Tappu Wildlife Reserve, it is also one of the 27 Important Bird Areas of Nepal (Baral \& Inskipp 2005). A total of 485 bird species has been recorded in this area (Baral 2005).

Grassy islands, small settlements and agricultural farms dominate north of Koshi Tappu $\left(26^{\circ} 47^{\prime} \mathrm{N}\right.$ \& $87^{\circ} 07^{\prime} \mathrm{E}$ ) extending over $70 \mathrm{~km}^{2}$. Parts of this area are annually inundated by the floodwaters of the Koshi River. Seasonally inundated areas have grasslands, large flood plains and banks that are covered with sand and gravel.

To the south of Koshi Tappu, lies the Koshi Barrage 


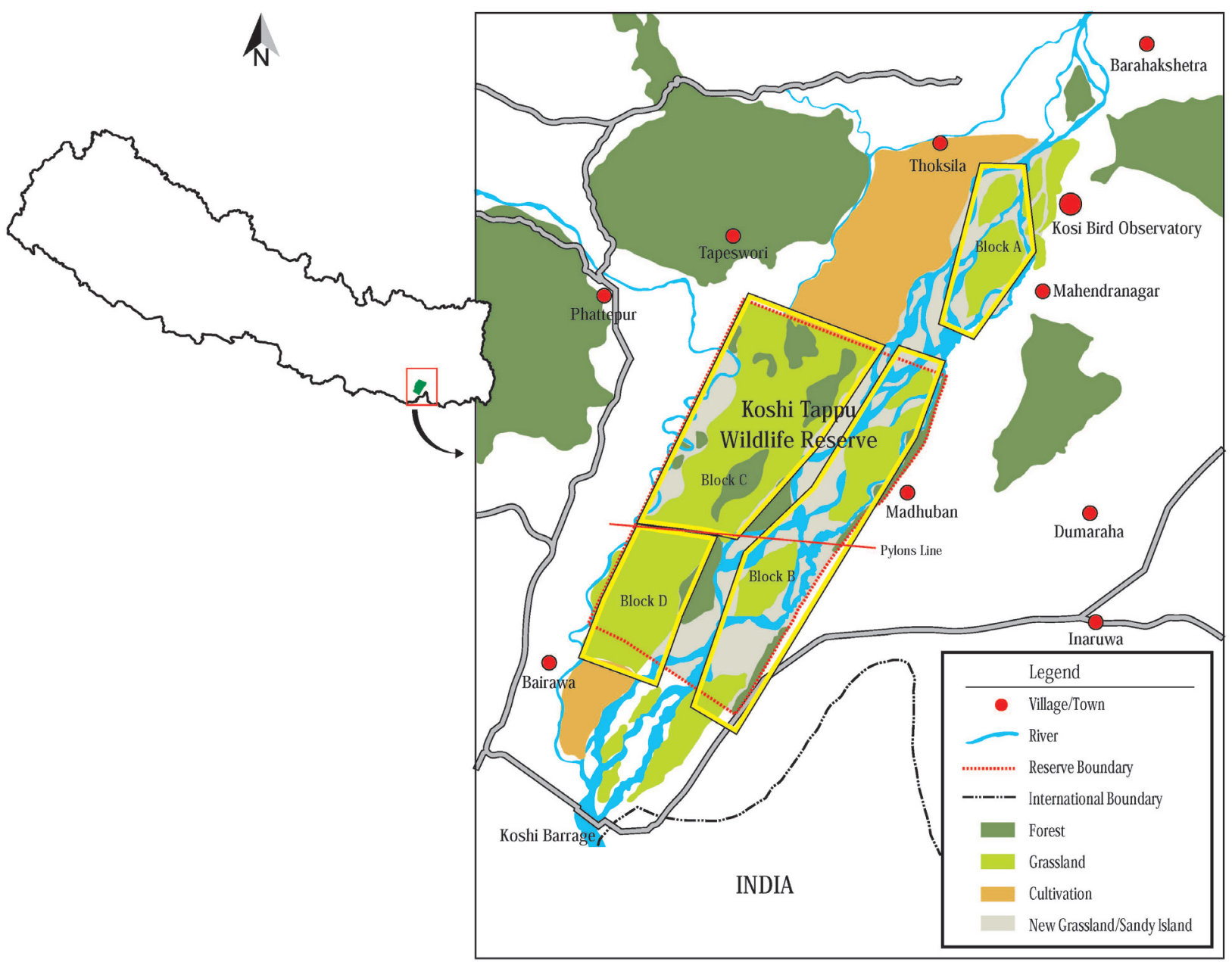

Figure 1. Map of Nepal showing Koshi Tappu Wildlife Reserve and the survey area

area $\left(26^{\circ} 36^{\prime} \mathrm{N} \& 87^{\circ} 03^{\prime} \mathrm{E}\right)$. This area is $7 \mathrm{~km}$ long from north to south and nearly $5 \mathrm{~km}$ east to west, totaling nearly $35 \mathrm{~km}^{2}$. More than $50 \%$ of the area is a wetland, and the remaining area is intensively cultivated throughout the year. During the dry season (October-March), several islands are vegetated with Saccharum spp., Imperata cylindrica and Typha elephantine which are collected by locals for household purposes.

To assist with stratifying the survey into manageable blocks, four blocks were identified as detailed below.

\section{Block A}

This block was the northernmost of the surveyed area and included the two islands outside Koshi Tappu Wildlife Reserve. Both islands were situated within Sunsari District. This block included the first island (centred at $26^{\circ} 45^{\prime} 57^{\prime \prime} \mathrm{N} \& 87^{\circ} 06^{\prime} 15^{\prime \prime} \mathrm{E}$; area: $4 \mathrm{~km}^{2}$ ) where grasslands were dominated by Saccharum spontaneum with smaller patches of Imperata grasses. Sward height was estimated (using ocular observations) at $50 \mathrm{~cm}$. This was the most northerly of the area surveyed during the study. This block also included the second island (centred at $26^{\circ} 44^{\prime} 40^{\prime \prime} \mathrm{N} \& 87^{\circ} 07^{\prime} 19^{\prime \prime} \mathrm{E}$; area: $14 \mathrm{~km}^{2}$ ). The grasslands of this island were dominated by $S$. spontaneum with fewer patches of Imperata spp. compared to the first island. The sward height was estimated at $50 \mathrm{~cm}$. There were approximately 10 ha of ploughed land, farmers temporarily living in thatch houses (10 houses counted), and maize fields.

\section{Block B}

Block B included three different sites, virtually covering the islands and areas close to the eastern dyke of Koshi River. First of all these were a small area $\left(0.1 \mathrm{~km}^{2}\right)$ north of Koshi Tappu (centred at $26^{\circ} 41^{\prime} 11^{\prime \prime} \mathrm{N}$ \& $87^{\circ} 05^{\prime} 38^{\prime \prime} \mathrm{E}$ ). This small island was covered with $S$. spontaneum grasses with a sward height estimated at $50 \mathrm{~cm}$. This block also included most parts of the Koshi Tappu lands on the east side of the main river channel along the eastern dyke of Koshi River, Sunsari District 
(centred at $26^{\circ} 39^{\prime} 43^{\prime \prime} \mathrm{N} \& 8^{\circ} 05^{\prime} 11^{\prime \prime} \mathrm{E}$; area: $6 \mathrm{~km}^{2}$ ). Three larger islands were visited and all had relatively taller grasses with sward height of about $150 \mathrm{~cm}$. Taller grasses and areas mixed with young riverine trees that formed very small patches of woodlands (approximately $5 \%$ of the area) were not covered. This block also included an area south of Koshi Tappu east of the main channel of the Koshi River, Sunsari District (centred at $26^{\circ} 33^{\prime} 49^{\prime \prime} \mathrm{N} \& 87^{\circ} 00^{\prime} 20^{\prime \prime} \mathrm{E}$; area: $9 \mathrm{~km}^{2}$ ). This area was the only one that started from within the Reserve and extended south up to the northern side of the Koshi Barrage (within the buffer zone of Koshi Tappu). Older islands (those formed more than two years ago) had been vegetated with grasses and Typha, whereas more recently formed islands within the last two years had some grasses and Casuarina plants. Saccharum and Imperata grasses had a sward height of about $50 \mathrm{~cm}$. On the newer islands, fresh shoots of the grasses had started growing, whereas in the older islands, grasses had been cut by the villagers. Some areas of the southern part were plain grounds due to overgrazing, and such areas were not included in the survey.

\section{Block C}

This was the largest of the blocks surveyed, west of the main channel of the Koshi River, north of the electric pylons. A small part of this block was in Udaypur District whereas rest of the area was in Saptari District. The Maria River flowing north-south was taken as the dividing point for the eastern block (within Block C) of the land that touched the western most channel of the Koshi River. The western block (within Block C) formed the western border of Koshi Tappu touching Udayapur District in the north and Saptari District on its south. The area was situated east of the Maria River (centred at 26039'34"N \& $87^{\circ} 02^{\prime} 34^{\prime \prime} \mathrm{E}$; area: $50 \mathrm{~km}^{2}$ ) and was characterised by Saccharum and Imperata grasslands with patches of young $D$. sissoo and $A$. catechu. In places where the ground was wetter, vegetation was dominated by $75 \%$ of Typha elephantine. Vegetation height here ranged from about $50-200 \mathrm{~cm}$. Near the southern border of the block large sand mounds deposited by the Koshi project could be seen. This block also included an area west of

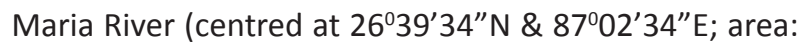
$55 \mathrm{~km}^{2}$ ). The habitat was very similar to that described in the eastern side. Comparatively more flowering Imperata were seen in this block and Cymbopogon sp. was growing in small areas in distinct clumps. These formed evenly spaced grass clumps growing to a height of about $50 \mathrm{~cm}$.

\section{Block D}

This block was situated on the west of the main channel of the Koshi River, south of the electric pylons, Saptari District (centred at 26037'51"N \& $87^{\circ} 01^{\prime} 19^{\prime \prime} \mathrm{E}$; area: $25 \mathrm{~km}^{2}$ ). Grasslands were dominated by Saccharum and Imperata species. The grass height varied considerably, and on average it was less than $50 \mathrm{~cm}$. This was the most disturbed of all the surveyed blocks. On the very southern side, south of Koshi Tappu, small human settlements were observed.

\section{METHODS}

Reconnaissance trips were made both in the eastern and the western side of the Koshi River between 24 March to 16 April by the staff of the Koshi Tappu Wildlife Reserve and Kosi Bird Observatory. On 21 and 22 April 11 surveyors, on 23 April, nine surveyors, and from 24 till 26 April, 12 surveyors took part in the grasslands survey for floricans. Surveys were conducted on foot after reaching the survey areas either by boats or by a four-wheel vehicle. All four blocks were covered for the survey (Table 1). Not all blocks were completely covered (see previous section). Surveys consisted of walking transects once within each block. A small island in Block B was covered twice, on 1 and 3 May 2012. This was done because of possible disturbance by people already present in the area on the first day of the visit (Image 1). Survey times were between 0500-1000 hr. This coincided with the time period when displaying male floricans were most active, and also when human use of the area was minimal. Major grass species and

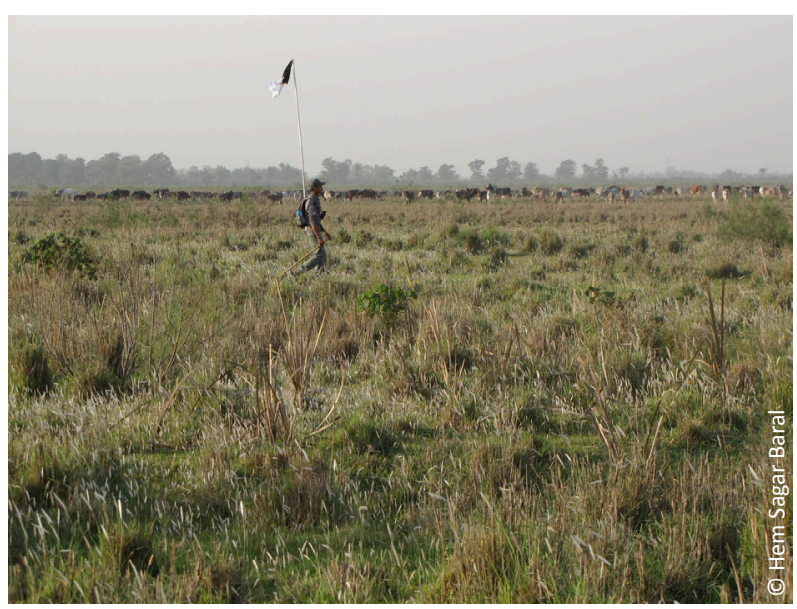

Image 1. Grassland Habitat, south of Koshi Tappu in Block B. Livestock in the background and survey team member seen in the foreground 
Table 1. Study blocks with numbers of Bengal Floricans sighted, livestock and people observed during the survey.

\begin{tabular}{|c|c|c|c|c|c|c|c|c|c|}
\hline Block & Area $\left(\mathrm{km}^{2}\right)$ & Date & $\begin{array}{c}\text { Male } \\
\text { floricans }\end{array}$ & $\begin{array}{c}\text { Female } \\
\text { floricans }\end{array}$ & $\begin{array}{c}\text { Total } \\
\text { floricans }\end{array}$ & Birds $/ \mathrm{km}^{2}$ & $\begin{array}{c}\text { Cattle/ } \\
\text { buffaloes }\end{array}$ & People & Threat remarks \\
\hline Block A & 18 & $\begin{array}{c}21 \& 22 \text { April } \\
2012\end{array}$ & 9 & 5 & 14 & 0.78 & 550 & 32 & $\begin{array}{l}\text { Registered land being } \\
\text { occupied, } 10 \text { temporary } \\
\text { sheds, ploughed land by } \\
\text { tractors and maize plantation } \\
\text { in around } 10 \text { ha }\end{array}$ \\
\hline Block B & 15.1 & $\begin{array}{c}23 \text { April; } \\
1 \text { \& } 3 \text { May } \\
2012\end{array}$ & 5 & 3 & 8 & 0.53 & 710 & 35 & $\begin{array}{l}\text { Heavy machinery works } \\
\text { ongoing by the Koshi Barrage } \\
\text { Authority, Bihar Government, } \\
\text { India; also disturbed by local } \\
\text { people and at least three } \\
\text { feral dogs hunting hares and } \\
\text { possibly birds }\end{array}$ \\
\hline Block C & 105 & $\begin{array}{c}24 \& 25 \text { April } \\
2012\end{array}$ & 14 & 9 & 23 & 0.22 & 1962 & 31 & $\begin{array}{l}\text { Largest number of cattle } \\
\text { encountered }\end{array}$ \\
\hline Block D & 25 & 26 April 2012 & 1 & 1 & 2 & 0.29 & 56 & 50 & $\begin{array}{l}\text { Largest number of people } \\
\text { encountered during the } \\
\text { survey, most disturbed part } \\
\text { of the areas surveyed inside } \\
\text { the reserve }\end{array}$ \\
\hline Total & 163.1 & & 29 & 18 & 47 & $\begin{array}{c}\text { Average } \\
\text { total density } \\
0.29\end{array}$ & 3278 & 148 & \\
\hline
\end{tabular}

vegetation type were noted with ocular observation of average sward height for grass.

All survey participants were familiar with floricans. Additional briefing on bird's nesting and tips on the surveyor's safety from Wild Water Buffalo, Elephant Elephas maximus, Leopard Panthera pardus and Wild Pig Sus scrofa were provided. Each of the participants used a pair of binoculars and selected participants were supplied with Bengal Florican survey forms. In addition, two digital cameras, two telescopes and one GPS were used throughout the survey. Two long poles with black and white clothes mimicking Bengal Florican's display were carried by two participants throughout the survey period. This was done assuming that it would stimulate male Bengal Floricans to display thus increasing detectability. We, however, did not measure its effectiveness. Participants carried watches to note the timing of Bengal Florican sightings and mobile phones to communicate about sightings of flying floricans to minimize double counts.

Although Koshi Tappu is a protected area, nearly 93,323 people living around the Reserve use the area (Conservation and Sustainable Use of Wetlands in Nepal 2009). In an attempt to measure the level of anthropogenic disturbance, we crudely estimated number of livestock and people seen using the area during the surveys. The total area surveyed was $163.10 \mathrm{~km}^{2}$ of which nearly half of the habitat was considered suitable for Bengal Florican. As much as $145 \mathrm{~km}^{2}$ of Koshi Tappu was thoroughly scanned; this constituted approximately $80 \%$ of the Reserve's core area. The remainder was outside the Reserve.

\section{Enumerating Bengal Floricans}

Double counting was minimized by matching sex and timing of bird sightings recorded in data sheets as well as via mobile phone when flying birds were seen. The nesting season of this species is from May to August (Oates 1898). We therefore assumed that the floricans had already established territories during the survey and were faithful to their sites, especially in the morning when disturbance was lower compared to the later part of the day. The total number of birds for each block was added to come up with the total number of birds counted in six days. Information on habitats at Koshi Tappu and adjoining areas were collected by field visits and also referring to the latest images available on the Google Earth. We covered $80 \%$ of the suitable habitat for Bengal Floricans in Koshi Tappu during the survey. We extended this estimate to the remaining $20 \%$ sites that could not be covered assuming that the unsurveyed habitat was also inhabited by Bengal Floricans to the same extent as the area that was covered. Estimates based on the assumption of equal sex ratio was not followed to estimate the population of Bengal Florican as such assumption may not be true with threatened taxon (Donald 2007).

Several aspects were recognized to be potential 
biases to counting the total florican population during this survey. Since only males displayed, counts were likely to be biased towards males. Grass height varied considerably across the survey areas, and we did not correct for detection bias due to variations in visibility. Bias due to different observers, timing of count, and varying levels of human disturbance were also recognized, but have not been corrected for. Potential variability introduced by the use of florican dummies was not estimated. The number of floricans that had not yet established territories during the survey was unknown. The possibility of birds moving between blocks over the entire survey period was recognized. The numbers obtained during the survey are therefore a crude estimate of floricans sighted during this survey in Koshi Tappu.

\section{RESULTS}

Bengal Floricans were recorded from all the blocks. The number of birds counted in the different blocks is given in a table (Table 1). A total of 47 Bengal Floricans was sighted, of which 14 were from outside the Koshi Tappu Wildlife Reserve and its buffer zone boundary, two birds in the buffer zone, and 31 from the core area of the Reserve.

Although 23 floricans were recorded from the Block C, Block A had a higher density of floricans (Table 1 ). Block $D$ with the least number of floricans indicated disturbance and heavy grazing. In Block B, all but one sighting, were from core area of the Reserve. If only the north island of the Block $A$ was considered, about three birds $/ \mathrm{km}^{2}$ were recorded from here, a very high density figure for this small island.

Assuming that the unsurveyed area had a density of floricans similar to the areas covered, we estimated the total population of floricans to be 60 . All the sites from where floricans were observed Imperata cylindrica was the dominant grass species and Saccharum spontaneum was a co-dominant species. Floricans were only recorded from grasslands that had $>50 \mathrm{~cm}$ sward height.

A total of 148 people and 3278 cattle/buffaloes was observed during the survey. Most people were seen collecting firewood and edible ferns. Cattle were recorded grazing in the grasslands during the morning when temperature was pleasant and then retiring to the woodland patches during the hotter part of the day. Presence of people and cattle at the time of the survey might have resulted in sighting fewer birds but we were unable to obtain conclusive evidence for this during our survey.

\section{DISCUSSION}

We enumerated 47 Bengal Floricans in the Koshi Tappu area. This is the highest known population in Nepal, and likely represents the highest known density of this species in South Asia.

Inskipp \& Inskipp (1983) have used several observation methods to record the bird's presence including early morning or evening visits lasting several days using hides, jeeps, elephant back or on foot. These methods have been repeated in subsequent studies and results are assumed to be comparable (e.g. Weaver 1991; Poudyal et al. 2008; Baral et al. 2003). The method used in the current survey is different from what has been practiced before. We also recognize many biases that have not been corrected for. Therefore a direct comparison of the counts in this paper with other work is not possible. Trends in population are therefore not estimable. Given the endangered status of the floricans and observed declines of grassland habitat, using more robust field and analytical methods to estimate florican population is necessary.

An earlier casual survey estimated 12 pairs of Bengal Florican in the Koshi area (Baral et al. 2012). It was thought that the estimate was very high given the disturbance at Koshi Tappu. However, the current survey has resulted in a count of 47 Bengal Floricans, which is nearly two times more than the previously estimated population for Koshi (Baral et al. 2012). Clearly, survey methods have serious implications on florican counts and require to be standardized.

Prior to this study, a total of 60 floricans was seen in Manas Wildlife Sanctuary in two consecutive years 1988 and 1989 (Rahmani et al. 1990). Similarly, in Dudhwa National Park 26 individuals were seen in the year 2001 (Rahmani 2001). There is no current population estimate from India as a whole, though on a global scale the country is certain to hold the largest Bengal Florican population in the world (BirdLife International 2012). Past florican estimates include assumptions such as equal sex ratio, and require to be updated using more robust methodology.

The total birds counted at Koshi area is the largest population of Bengal Florican recorded in Nepal. This number from such a small area may mean that Koshi has the densest population of Bengal Floricans in South Asia. The Manas National Park with $391 \mathrm{~km}^{2}$ and the Dudhwa National Park with $614 \mathrm{~km}^{2}$ are significantly 
larger protected areas compared to the Koshi Tappu Wildlife Reserve $\left(175 \mathrm{~km}^{2}\right)$. In Koshi, the northern island with the smallest area has the largest number of the Bengal Floricans for its size (Table 1). Together with the much larger southern island, the total number of Bengal Florican comes to 14 birds (nine males and five females). This is undoubtedly the largest population of Bengal Florican outside any protected area and buffer zone in Nepal.

Recent estimates of the species' global population range from 250-999 individuals (BirdLife International 2012). The methods used to reach these estimates are unknown, which underscores the uncertainty inherent in global estimates. It is therefore difficult to know what proportion of the global population is represented by the count in the Koshi Tappu area alone.

Such a large number of florican in the Koshi Tappu area has been attributed to the improvement in their habitat since last year, reduced grazing, and increased coverage of the suitable habitats during the survey (Baral et al. 2012). Reduced grazing may have favoured increase of grass height allowing more floricans to use the area. However, the impacts of grazing are poorly known. Heavy grazing can reduce grass height removing cover for birds while removal of grazing may increase grass heights for Bengal Florican which is known to favour mostly short grasses (Baral 2001; Poudyal et al. 2008). This study has supported earlier studies regarding species' habitat utilisation during breeding, viz., Imperata-Saccharum assemblage (Inskipp \& Inskpp 1983; Baral 2001; Poudyal et al. 2008). Detailed grassland ecology studies combined with studies on the ecology of the floricans are necessary to understand mechanisms that help improve local populations.

There are also several threats operating simultaneously for the Bengal Florican. These include disturbance caused by human and their livestock especially during breeding, inappropriate grassland management, increased predation, loss and degradation of its suitable habitat (Baral et al. 2012). Although evidence is absent, poaching may be occurring. The following recommendations aim to reduce threats to Bengal Floricans and are essential for its conservation in Koshi Tappu and its adjoining area.

1. Understanding habitat needs of the Bengal Florican. Conducting grassland management studies is vital before specific recommendations for habitat management can be provided. Grass species, height, grazing levels, impacts of flooding and impacts of burning are all suspected to affect grassland habitats and therefore floricans. All of these aspects require to be studied in greater detail, and results incorporated in regional and national plans to help improve florican habitat.

2. Grasslands are declining outside of protected areas. Preserving them via purchase and private management is an option that requires exploration.

3. Use of grasslands for grazing, agriculture and other purposes was seen during this survey, and in other locations in Nepal and India. Integrating the needs of the local people with the conservation requirements of floricans is vital. Initiating integrated multi-disciplinary projects to improve protected area management alongside human use of grassland areas is necessary. Creating site-specific awareness and education programmes directed at specific threats is necessary.

4. Direct disturbance by the use of heavy machinery was observed in Koshi Tappu. Regulating the use of machinery and avoiding their use during the breeding season will assist florican management greatly.

5. Documenting threats to floricans and improving our understanding of their population biology is necessary. Surveys have helped identify areas with floricans, and future efforts using improved methodology can assist to better understand the threats faced by floricans and their ecological requirements.

\section{REFERENCES}

Ali, S. \& S.D. Ripley (1987). Compact Handbook of The Birds of India and Pakistan. Oxford University Press, New Delhi, xiii+737pp+104 colour plates.

Baral, H.S. (2001). Community Structure and Habitat Associations of Lowland Grassland Birds in Nepal. University of Amsterdam and Cardiff University. Amsterdam and Cardiff, 235pp.

Baral, H.S. (2005). Birds of Koshi. Second edition. Department of National Parks and Wildlife Conservation, Participatory Conservation Programme and Bird Conservation Nepal. Kathmandu, 24pp.

Baral, H.S. \& C. Inskipp (2005). Important Bird Areas in Nepal: Key Sites for Conservation. Bird Conservation Nepal, Kathmandu and BirdLife International, Cambridge, 242pp.

Baral, H.S., A.K. Ram, B. Chaudhary, S. Basnet, H. Chaudhary, T. Giri \& D. Chaudhary (2012). Conservation status of Bengal Florican Houbaropsis bengalensis bengalensis (Gmelin, 1789) (Gruiformes: Otididae) in Koshi Tappu Wildlife Reserve and adjoining areas, eastern Nepal. Journal of Threatened Taxa 4(3): 2464-2469; http:// dx.doi.org/10.11609/JoTT.o2948.2464-9

Baral, N., N. Timilsina \& B. Tamang (2003). Status of Bengal Florican Houbaropsis bengalensis in Nepal. Forktail 19: 51-55.

BirdLife International (2012). Species factsheet: Houbaropsis bengalensis. Downloaded from http://www.birdlife.org on 24 May 2012.

Conservation and Sustainable Use of Wetlands in Nepal (2009). Baseline Survey Report, Koshi Tappu Wildlife Reserve, 3pp.

Hoyo, J.D., A. Elliott \& J. Sargatal (1996). Birds of the World. Volume 3. Lynx Edicions, Barcelona, 821pp.

Donald, P.F. (2007). Adult sex ratios in wild bird populations. Ibis 149(4): 
671-692; http://dx.doi.org/10.1111/j.1474-919X.2007.00724.x Inskipp, C. \& N.J. Collar (1984). The Bengal Florican: its conservation in Nepal. Oryx 18(1): 30-35.

Inskipp, C. \& T. Inskipp (2001). A re-visit to Nepal's lowland protected areas. Danphe 10(1/2): 4-7.

Inskipp, C. \& T.P. Inskipp (1983). Report on a survey of Bengal Floricans Houbaropsis bengalensis in Nepal and India, 1982. Study Report No. 2. International Council for Bird Preservation, Cambridge, U.K., $54 \mathrm{pp}$.

Oates, E.W. (1898). A Manual of The Game Birds of India. A J Combridge and Company, Bombay, ix+431pp.

Peet, N., A.J. Watkinson, D.J. Bell \& B.J. Kattel (1999). Plant diversity in the threatened subtropical grasslands of Nepal. Biologica Conservation 88: 193-206; http://dx.doi.org/10.1016/S00063207(98)00104-9

Pokharel, C.P. \& N.P. Dhakal (1998). Status of Bengal Florican Eupodotis bengalensis in Royal Bardia National Park, western lowland, Nepal. Unpublished report to the Oriental Bird Club, U.K., iii+12pp.

Poudyal, L.P., P.B. Singh \& S. Maharajan (2008). Bengal Florican Houbaropsis bengalensis in Nepal: an update. Birding Asia 10:4347.

Rahmani, A.R. (2001). Status of the Bengal Florican Houbaropsis bengalensis in Uttar Pradesh, India. The Bombay Natural History Society, Mumbai, 12pp.

Rahmani, A.R., G. Narayan, L. Rosalind \& R. Sankaran (1990). Status of the Bengal Florican in India, pp. 55-78. In: BNHS (ed.). Status and Ecology of the Lesser and Bengal Floricans with Reports on Jerdon's Courser and Mountain Quail. Bombay Natural History Society, India, $155 \mathrm{pp}$.

Sah, J.P. (1997). Koshi Tappu Wetlands: Nepal's Ramsar Site. IUCN Bangkok, Thailand, xviii+254pp.

Weaver, D. (1991). A survey of Bengal Floricans Houbaropsis bengalensis at Royal Suklaphanta Wildlife Reserve and Royal Bardia National Park, western Nepal. Report to Oriental Bird Club. Unpublished, 14pp+viii.
Nepali Abstract: खरमुजुर विश्वमै अति संकटापन्न अवस्थामा रहेको लोपोन्मुख पंछीको एक प्रजाति हो। नेपालमा विक्रम सम्वत २०३९ साल देखि पटक-पटक यस प्रजातिको संख्या अनगमन भइरहेको र संरक्षित क्षेत्रहरूमा मात्र पाइने भएता पनि हालै गरिएको एक अध्ययन प्रतिवेदन अनुसार यसको संख्या निकै घटेको पुष्टि भएको थियो। गत वर्ष (२०६९ सालको बैशाख महिनामा) कोशी टप्प र आसपासका विभिन्न घाँसेमैदान हिंडेर योजनाबद्ध रुपमा यस प्रजातिको सर्वेक्षण सम्पन्न गरि यो। यस सर्वेक्षणमा जम्मा $४ ७$ वटा खर मुजुरको गन्ती गरियो जुन संख्या नेपालको सबैभन्दा ठुलो र संभवत भारतीय उपमहाद्वीपमै सबैभन्दा बढ़ी घनत्व भएको हुन सक्छ। यस सर्वेक्षणका आधारमा को शी र आसपासका घाँसेमैदानमा खरमुजुरको संख्या ६० रहेको अनुमान गरियो। खरमुजुरको दिगो संर क्षणका लागि यस वैज्ञानिक पत्रमा विभिन्न सकावहरू प्रस्तुत गरिएको छ।

\section{Author Details:}

HEM SAGAR BARAL has a PhD in eology of grassland birds from the University of Amsterdam, The Netherlands. He has been involved in bird conservation for last 25 years. He has held important positions for BirdLife Nepal, founded charities like Himalayan Nature and Nepalese Ornithological Union and currently is an adjunct professional for the School of Environmental Sciences, Charles Sturt University, Australia based in Kathmandu.

ASHOK KUMAR RAM holds a BSc in Forestry and is the Conservation Officer of Kosh Tappu Wildlife Reserve. He has been actively involved in wildlife conservation and management as a government officer of the Department of National Parks and Wildlife Conservation.

BADRI CHAUDHARY is Nepal's one of the leading field ornithologists based at Koshi Tappu Wildlife Reserve. He is closely affiliated with Himalayan Nature and its various activities including Kosi Bird Observatory.

DHIRAJ CHAUDHARY is a young field birder currently based at Koshi Camp, a facility that provides tours and accommodation for visitors to Koshi Tappu Wildlife Reserve.

ANISH TIMSINA is a young field birder currently based at Koshi Camp, a facility that provides tours and accommodation for visitors to Koshi Tappu Wildlife Reserve. SUMAN ACHARYA is a young field birder member of Koshi Bird Society, a local bird club at the edge of Koshi Tappu Wildlife Reserve.

KRISHNA BIDARI is a field birder currently based at Koshi Camp, a facility that provides tours and accommodation for visitors to Koshi Tappu Wildlife Reserve. SANJIB ACHARYA is a research assistant working at the Kosi Bird Observatory, Centre for Grassland and Wetland Studies, Koshi and is managed by Himalayan Nature.

BINOD ACHARYA is a young field birder member of Koshi Bird Society, a local bird club at the edge of Koshi Tappu Wildlife Reserve.

PREM THULUNG is a young field birder member of Koshi Bird Society, a local bird club at the edge of Koshi Tappu Wildlife Reserve.

ARJUN KARKI is a forest guard in a community managed forests in the buffer zone of Koshi Tappu Wildlife Reserve and is a member of Koshi Bird Society.

KRISHNA PRASAD ACHARYA has an Msc in natural resources management. He has written several research papers on biodiversity issues, was the Head of Environment Division in the Ministry of Forests and Soil Conservation. He is currently the Director General of the Department of National Parks and Wildlife Conservation since two years.

Author Contribution: The study coordination and paper writing was done by Hem Sagar Baral with contributions from the co-authors in field observations and editing. 